\title{
Exploration of the Level of Interest and Performance of Beef Attributes in Supermarket in District of South Bolaang Mongondow, Indonesia
}

\author{
Erwin Wantasen*, Sintya Jummoni Krissanty Umboh, Eusebius Kussoy Malingkas Endoh \\ Department of Socio-Economy, Faculty of Animal Husbandry, The Sam Ratulangi University, Jalan Kampus Manado, Indonesia \\ Email address: \\ erwinwantasen@yahoo.co.id (E. Wantasen), sintyaumboh@yahoo.com (S. J. K. Umboh), endoh_tol@yahoo.co.id (E. K. M. Endoh) \\ ${ }^{*}$ Corresponding author
}

To cite this article:

Erwin Wantasen, Sintya Jummoni Krissanty Umboh, Eusebius Kussoy Malingkas Endoh. Exploration of the Level of Interest and Performance of Beef Attributes in Supermarket in District of South Bolaang Mongondow, Indonesia. Journal of Business and Economic Development. Vol. 4, No. 3, 2019, pp. 90-96. doi: 10.11648/j.jbed.20190403.13

Received: July 25, 2019; Accepted: August 21, 2019; Published: September 10, 2019

\begin{abstract}
This research is aimed to analyze consumer behavior in purchasing beef at modern market, located in District of South Bolaang Mongondow, Province of North Sulawesi, viewed from level of interest and performance of various attributes closely attached to beef products. The research, methodologically, then, was performed under survey method to beef's consumers in two supermarkets existing in District of South Bolaang Mongondow. Both supermarkets selected as research site were Media Trans and Hail Mart, having been newly operated since 2018. 100 respondents were selected with accidental sampling technique, 50 respondents of each supermarket respectively. Data obtained were primary data, comprising of consumers' perception against 25 items of beef attributes in-depth questioned under guidance of list of questions prepared initially. To analyze the level of interest and performance of beef attributes sold according to consumers' perception, importance-performance matrix (IPM), thus, was employed. A value given for the level of interest and performance had 5 indicators, ranging of 1-5. As a result, the research concludes that attribute of expired dated, contents of beef's parts and information of halal (under religious practice) were significantly important; however, the performance had not been in accordance with consumers' expectation in influencing purchasing decision. Therefore, as further recommendation, those beef attributes are necessarily required higher priority by management of both supermarkets and beef's producers in improving beef's quality in order to satisfy consumers' demand in purchasing beef products.
\end{abstract}

Keywords: Consumer Behavior, Supermarket, Expired Date, Contents of Beef's Parts, Halal

\section{Introduction}

Beef is one of protein sources in husbandry's products, easily found in either modern or traditional market. In line with rapid development and competition among beef's producers, a demand of improvement in all aspects becomes highly concerned in order to attract consumers' intention and perception. Shopping destination by considering all aspects of consumers' convenience and satisfaction can be found in modern market and supermarket. The existence of modern market providing numerous daily needs considerably assists consumers in shopping, although its prices offered are slightly more expensive than prices offered in traditional market $[1,2]$.
Modern market or grocery stores comprising of minimarket, supermarket, or hypermarket is retail entity selling various types of goods classified into several parts arranged carefully to ease in searching certain goods or purpose. Characteristics of modern market, then, provides wide, clean, comfortable shopping place and ordered layout, so that consumers can easily find goods demanded.

The distribution of modern market itself can be seen in several places in Indonesia. One of it is located in the District of South BolaangMongondow. It is one of Districts in Province of North Sulawesi, having been just enfolded since 2010 of its main district, District of BolaangMongondow. Economically, region in District of South Bolaang Mongondow has relatively small economic growth, 2,45\% 
[3]. In fact, this region has potency well enough in agriculture, including sub-sector of husbandry, having contribution against local economy of District of South BolaangMongondowof 5,4\% in 2017 [3]. This condition is arguably caused by less performance of sub-sector of local economy in boosting up totally local economy development, including sub-sector of husbandry.

One of significant aspects in improving sub-sector of husbandry of certain region is marketing husbandry sector along its products. To achieve such purpose, there are one traditional market, having been operated in 2008, and two supermarkets, having newly operated since 2018, in District of South BolaangMongondow; where one of products sold is beef. In theory of modern marketing, consumer behavior playing significant role is highly considered by producers, so that it will be expectedly able to attract consumers' appeal in purchasing and consuming products offered. Whereas a company cannot be able to directly influence consumers in purchasing, a company should understand consumers' demand by studying their behavior in that consumers willingly purchase certain products [4].

Based on its products sold, beef is one of the most favorable consumed livestock products by people living in District of South BolaangMongondow. Several attributes of beef considered by consumers in purchasing it are freshness, price, beef's color, hygiene, special odor/smell, texture, nonfatty, packaging, and beef's tenderness $[5,6]$.

Some previous research's findings on consumer behavior of beef in modern and traditional market showed that factors of marketing mix attribute, such as nutrition, price, packaging, color, texture, fat information, halallabel, advertisement, promotion, hygiene, accessible with transportation modes, and product availability are significantly influenced on consumer behavior in purchasing beef [7-11]. Meanwhile, information of attribute effects comprising of beef's content, beef slices, cash payment method, payment method by credit card, outlet of separated beef selling, consumers counseling by employee, service acceleration in counter, supply continuity, brochure, toilet, storage's temperature, and information of expired date against consumer's decision were limited. Hence, this research aimed to analyze consumer behavior in purchasing beef in supermarket located in District of South BolaangMongondow Province of North Sulawesi that has not been ever performed previously by consideration that there are only two modern markets selling beef in this region; and those supermarkets have been just operated since 2018, so that consumers have not been accustomed to shop beef products in both supermarkets. All this time, consumers located in research site only buy beef from traditional market, having different situation with modern market, so having known consumer behavior on various attributes of beef can expectedly be a fundamental base in arranging strategic policy to attract intention of beef's consumers in purchasing beef products and it will improve local economy development since there is production improvement and beef's consumption in this region.

\section{Research Method}

\subsection{Site, Time of Research, Type and Source of Data}

This research was done in Hail Mart and Media Trans supermarket, located in Sub-district of BolangUki, District of South BolaangMongondow, Province of North Sulawesi. An underlying issue took both shopping centers as research site was that both supermarkets only sell beef and there are relatively new in town. Therefore, it was necessarily to acknowledge how to position good image for consumers in making purchasing decision. The research was performed during February- March 2019. Data used in this research was two types, primary and secondary. Primary data was, then, analyzed from the survey result to respondents of beef's consumers in Media Trans and Hail Mart supermarket. While, secondary data used was information obtained from related governmental institutions, such as Commerce Service, District of South BolaangMongondow, scientific journals, and internet.

\subsection{Data Collecting Method and Sampling Technique}

Data gathered in this research were obtained from in-depth interview by using a list of questions, containing a series of questions or written statementsprovidedto respondents in answering [12]. Population of this research, thus, was in large size and its number was unknown specifically, so that, according to that $[13,14]$ to determine total of samples derived from unknown number of populations, it can use following formulation:

$$
n=\frac{Z^{2}}{4(M o e)^{2}} n=\frac{1,96^{2}}{4(0,05)^{2}} n=\frac{3,841}{0,04}=96,025
$$

$\mathrm{n}=$ total of samples

$\mathrm{Z}=$ level of faith in determining sample of $95 \%=1,96$

$\mathrm{Moe}=$ margin of erroror tolerably maximal error

The result of measurement obtained total of samples of 96,025 , accumulated into 100 , and, it was determined by non-probabilitysampling method using accidental sampling. Every supermarket located in research site was, then, selected 50 respondents respectively by accidental sampling.

Further, there were 25 attributes of beef products becoming focus of the research classified into marketing mix variables. It can be seen from following Table 1 , as hereunder:

Table 1. Research variables.

\begin{tabular}{ll}
\hline Marketing Mix Variables & Attributes \\
\hline & Nutrition \\
& Beef's Color \\
& Texture \\
& Packaging \\
& Halal Label \\
& Beef's Parts \\
Products & Beef's Slices \\
& Fat Information \\
& Information of Expired Date \\
& 10. Storage's Temperature \\
Price & Price Level \\
\hline
\end{tabular}




\begin{tabular}{ll}
\hline Marketing Mix Variables & Attributes \\
\hline & Cash Payment Method \\
& Payment Method by Credit Card \\
& Accessible by transportation modes \\
& Consumers Service Counseling by \\
& Employee \\
Places & Separated Outlet \\
& Discount \\
Promotion & Brochure \\
& Parking Lot \\
& Continuity of Beef Availability \\
Physical Evidence & Toilet \\
& Hygiene \\
Process & Service Acceleration in Counter \\
Human Resources & Employee's Hospitality \\
Consumer Behavior & Employee's Uniform Tidiness \\
\hline
\end{tabular}

\subsection{Data Analysis}

To answer the purpose of this research, importance performance analysis (IPA) method was employed to map attributes' appearance and performance in the Table 1 according to consumers' perception. By this analysis model, it would obtain significant types of attributes and its worse performance based on consumers, so it would refine attributes' performance in order to satisfy consumers' demand. In addition, importance performance analysis was aimed to know condition of each of marketing mix attributes viewed from interest and performance by following formulation, as hereunder [15-17].

$$
\begin{aligned}
& \overline{\mathrm{X}}=\sum X i / N \\
& \overline{\mathrm{Y}}=\sum Y i / N
\end{aligned}
$$

$\bar{X}$ : Mean of performance level from all attributes of beef

$\bar{Y}$ : Mean of interest level from all attributes of beef

$\mathrm{Xi}$ : Mean of performance level

Yi: Mean of interest level

$\mathrm{N}$ : Total of respondents

Moreover, to analyze level of interest and performance according to consumers' perception importance-performance matrix (IPM) was then utilized. Value provided for level of interest and performance had 5 indicators, as seen in following Table 2,

Table 2. Score/value of level of interest and performance.

\begin{tabular}{lll}
\hline Level of interest (Y) & Level of performance (X) & Score/value \\
\hline Highly not important & Highly poor & 1 \\
Not important & Poor & 2 \\
Fair & Fair & 3 \\
Important & Good & 4 \\
Highly important & Better & 5 \\
\hline
\end{tabular}

Input fromimportance performance matrix was respondents' answer against level of interest and performance of every attribute questioned. Also, each attribute would be mapped in a Kartesius diagram, where $\mathrm{Y}$ is importance and $\mathrm{X}$ is performance $[18,19]$.

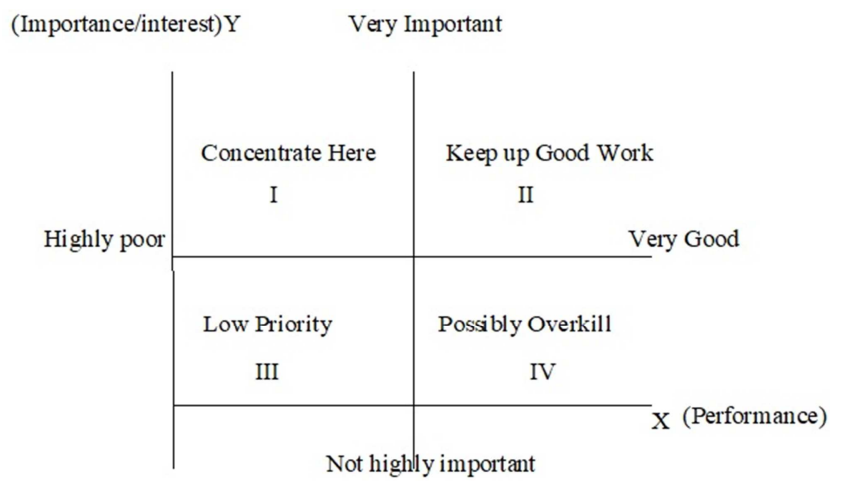

Figure 1. Kartesius Diagram.

1) Quadrant I/Concentrate Hereis mean of interest between 3.00-5.00 and performance of 1.00-2.99 showing higher interest, but low in performance. It means that interest concentration is necessarily required in improving quality of attributes service and there is a system requiring promptly improvement and it should be given a higher priority.

2) Quadrant II/Keep up good work is mean of interest between 3.00-5.00 and performance of 3.00-5.00. It shows that level of interest and performance are higher, labelled as "Keep up good work", meaning attribute of service is above average considered by consumers and well-performed, so that consumers are satisfied (good work is continued).

3) Quadrant III/Low Priority is mean of level of interest and performance of 1.00-2.99 and 1.00-2.99 respectively. It describes that performance value does not meet with quality standard of services, but it places lower level of interest against services (low priority is due to not being concentrate here). Service element reasonably performed is less concerned by marketers and not considered as significant point by consumers.

4) Quadrant IV/Possibly Overkillismean of interest ranging of 1.00-2.99 and performance of 3.00-5.00, respectively as lower interest and higher performance. Service element not significantly important by consumers is well-performed by marketers as possibly overkill.

\section{Findings and Discussion}

The consumer behavior of beef in supermarkets located in District of South Bolaang Mongondow was analyzed by Importance Performance Analysis (IPA) to know consumers' perception against various attributes in beef sold. Then, the analysis result is presented in Table 3, depicting average value of level of interest and performance from 25 attributes of beef according to consumers' respond. 
Table 3. Consumers' Perception against level of interest and performance on beef's attributes.

\begin{tabular}{|c|c|c|c|c|}
\hline Attributes & Value of Interest & Rank & Value of Performance & Rank \\
\hline Expired date & 4.93 & 1 & 1.39 & 25 \\
\hline Service acceleration in counter & 4.74 & 2 & 4.34 & 2 \\
\hline Hygiene of selling point & 4.70 & 3 & 4.66 & 1 \\
\hline Beef's texture & 4.61 & 4 & 3.97 & 13 \\
\hline Beef's parts & 4.61 & 5 & 1.74 & 24 \\
\hline Nutritional contents & 4.59 & 6 & 4.02 & 10 \\
\hline Beef's color & 4.56 & 7 & 3.97 & 12 \\
\hline Price & 4.54 & 8 & 3.98 & 11 \\
\hline Accessible location & 4.50 & 9 & 3.95 & 14 \\
\hline Cash payment & 4.40 & 10 & 4.13 & 4 \\
\hline Discount & 4.32 & 11 & 2.41 & 21 \\
\hline Parking lot availability & 4.27 & 12 & 4.04 & 7 \\
\hline Supply continuity & 4.26 & 13 & 4.03 & 8 \\
\hline Employee's hospitality & 4.25 & 14 & 4.02 & 9 \\
\hline Toilet & 4.12 & 15 & 4.12 & 5 \\
\hline Employee's uniform tidiness & 4.06 & 16 & 4.24 & 3 \\
\hline Beef's parts and slices & 3.96 & 17 & 3.50 & 18 \\
\hline Fat information & 3.88 & 18 & 3.73 & 16 \\
\hline Separated outlet & 3.85 & 19 & 2.61 & 20 \\
\hline Halal label & 3.82 & 20 & 1.96 & 23 \\
\hline Storage's temperature & 3.71 & 21 & 3.90 & 15 \\
\hline Payment method by credit card & 3.45 & 22 & 4.06 & 6 \\
\hline Brochure & 3.39 & 23 & 2.32 & 22 \\
\hline Service counseling by employee while purchasing & 3.33 & 24 & 3.64 & 17 \\
\hline Packaging & 3.14 & 25 & 3.16 & 19 \\
\hline
\end{tabular}

From above, Table 3 demonstrates that attribute of expired date was highly considered by consumers; it showed by a higher average value of interest, but average value of performance of this attribute was at the lowest place among 25 attributes observed by consumers. Thus, attribute of expired date was required high priority by producers and management of modern markets in attracting consumers to buy beef. While, consumers considered attribute of packaging as highly not important; where its average value of interest was the lowest and its attribute of performance was still classified into the lowest according to consumers, placed in 19 of 25 attributes analyzed. This attribute, then, had low priority to be developed in purchasing decision. These findings are in accordance with previous study, arguing that packaging factor was not main determiner in purchasing decision by consumers, but beef's texture and price were deemed important to be considered by producers and marketers $[20,21]$. Nonetheless, this research is unlike with others investigation reporting that attribute of packaging was highly important to maintain beef's security, hygiene, and quality, so that its hygiene and security were well-protected to be consumed [22-24]. Additionally, to know what attributes became high priority to be developed or improved its performance and attributes had to be maintained its performance to achieve consumers' satisfaction on beef products, a measurement of suitability level (Tki) was performed, comparing mean of performance with mean of interest. By the end of calculation, suitability level could determine priority scale of improvement and services in order to increase consumers' satisfaction.

Table 4. Suitability level of attributes based on its mean of Interest and performance.

\begin{tabular}{|c|c|c|c|c|}
\hline No & Name of Attributes & Suitability Level (Tki) (\%) $(\underset{\bar{Y}}{\bar{Y}} \mathbf{X} 100 \%)$ & Mean of Interest & Mean of Performance \\
\hline 1 & Nutrition & 87.58 & 4.59 & 4.02 \\
\hline 2 & Color & 87.06 & 4.56 & 3.97 \\
\hline 3 & Texture & 86.12 & 4.61 & 3.97 \\
\hline 4 & Halal label & 51.31 & 3.82 & 1.96 \\
\hline 5 & Beef's parts & 37.74 & 4.61 & 1.74 \\
\hline 6 & Beef's slices & 88.38 & 3.96 & 3.50 \\
\hline 7 & Fat information & 96.13 & 3.88 & 3.73 \\
\hline 8 & Expired date & 28.19 & 4.93 & 1.39 \\
\hline 9 & Storage's temperature & 105.12 & 3.71 & 3.90 \\
\hline 10 & Price level & 87.67 & 4.54 & 3.98 \\
\hline 11 & Cash payment method & 93.86 & 4.40 & 4.13 \\
\hline 12 & Payment method by credit card & 94.61 & 4.27 & 4.04 \\
\hline 13 & Accessible place & 87.78 & 4.50 & 3.95 \\
\hline 14 & Separated outlet & 67.79 & 3.85 & 2.61 \\
\hline 15 & Discount & 55.79 & 4.32 & 2.41 \\
\hline 16 & Brochure & 68.44 & 3.39 & 2.32 \\
\hline 17 & Packaging & 100.64 & 3.14 & 3.16 \\
\hline 18 & Parking lot availability & 94.61 & 4.27 & 4.04 \\
\hline
\end{tabular}




\begin{tabular}{lllll}
\hline No & Name of Attributes & Suitability Level (Tki) $(\mathbf{\%})\left(\frac{\bar{x}}{\overline{\mathrm{Y}}} \mathbf{X} \mathbf{1 0 0} \%\right)$ & Mean of Interest & Mean of Performance \\
\hline 19 & Beef's supply continuity & 117.68 & 3.45 & 4.06 \\
20 & Toilet & 100.00 & 4.12 & 4.12 \\
21 & Hygiene of selling point & 99.15 & 4.70 & 4.66 \\
22 & Service acceleration in counter & 91.56 & 4.74 & 4.34 \\
23 & Service counseling by employee & 109.31 & 3.33 & 3.64 \\
24 & Employee's hospitality & 94.59 & 4.25 & 4.02 \\
25 & Employee's uniform tidiness & 104.43 & 4.06 & 4.24 \\
Total of mean & 85.42 & 4.16 & 3.52 \\
\hline
\end{tabular}

According to the calculation result of Suitability Level (Tki) as seen in above Table 4, mean of suitability level was $85,42 \%$, having value range about $28,19 \%$ up to $117,68 \%$. Attribute having value of $28,19 \%$ was expired date. It, thus, depicts that expired date was arguably deemed not in accordance with consumers' demand, so that improvement and concern in this attribute would be necessarily done by company. Whereas, attribute having value of $117,68 \%$ was supply continuity. In this attribute, value of supply continuity had been in accordance with consumers' demand, but its quality had to be necessarily maintained and concerned.

In addition, Table 4 explains that relation of suitability and level of interest and performance, according to consumers' perception, had been suitable with previous researcher's, arguing that if suitability percentage ranges $80-100 \%$, performance of each attribute has been satisfied consumers' demand; however, improvement should be done further [25$28]$. On the other hand, if percentage is $>100 \%$, performance of such attribute has exceeded beyond consumer's demand; and, if percentage is $<80 \%$, performance of such attributes has not met consumers' demand.

Mean of each attribute based on Table 4 was, then, used in determining its position in the Kartesius diagram (Figure 2). In this diagram, description of each attribute of $\overline{\mathrm{X}}$ and $\overline{\mathrm{Y}}$ was divided into four quadrants and limited by mean of performance level of overall attributes under 3,52, and mean of interest level was 4.16.

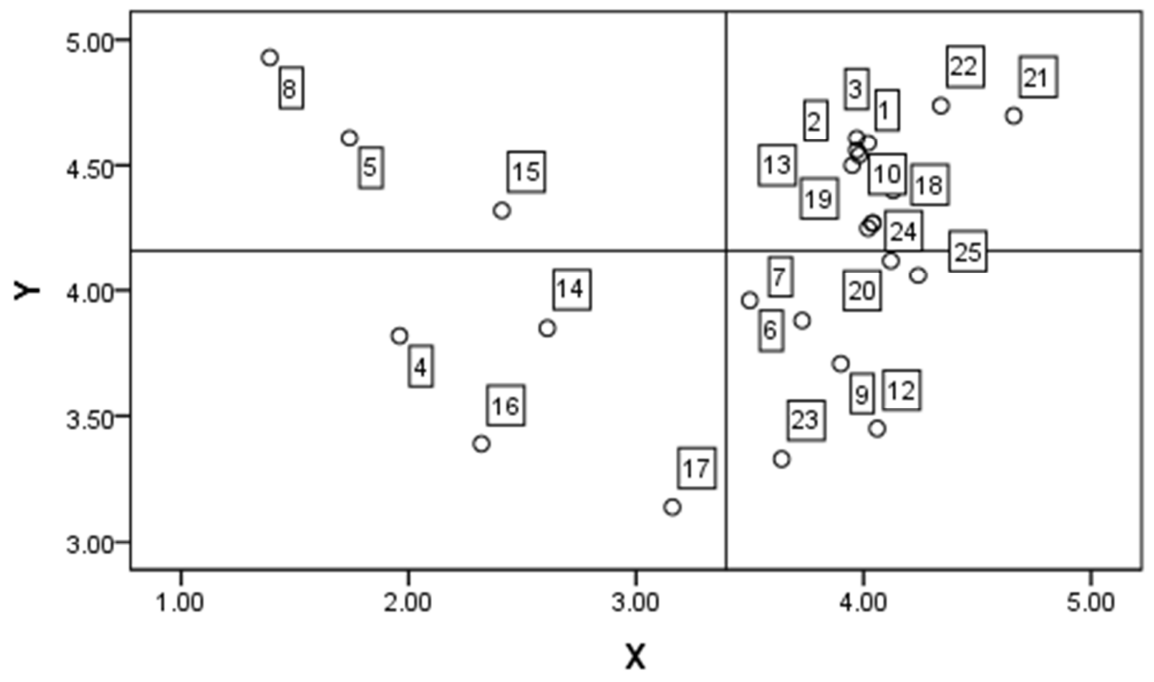

Figure 2. Attributes Mapping based on the Kartesius Diagram.

Note: 1. Nutrition, 2. Color, 3. Texture, 4. Halal label, 5. Beef's parts, 6. Beef's slices, 7. Fat information, 8. Expired date, 9. Storage's temperature, 10. Price level, 11. Cash payment method, 12. Payment method by credit card, 13. Accessible location, 14. Separated outlet, 15. Discount, 16. Brochure, 17. Packaging, 18. Parking lot availability, 19. Supply continuity, 20. Toilet, 21. Hygiene of selling point, 22. Service acceleration in counter, 23. Service counseling by employee, 24. Employee's hospitality, 25. Employee's uniform tidiness.

Specifically, position of such quadrants described different condition. This mapping was according to level of interest and performance enabling management of supermarkets to immediately make improvement in those attributes considered important by consumers. Furthermore, each quadrant could be explained by following interpretations, as follows:

1. Quadrant I depicted any factors considered important and expected by consumers, but producers' performance had not provided any optimal satisfaction to consumers, so that consumers felt disappointed. This dimension had to be prioritized in improvement by management of supermarkets and beef's producers. Attributes classified into Quadrant I were Beef's parts, expired date, and discount.

2. Quadrant II was the most expected and demanded quadrant by consumers. These attributes had been in line with consumers' demand and considered as important factors and supporting factors of consumers' satisfaction, so that management of supermarkets had maintained this achievement. Attributes included in this quadrant were nutrition, price level, cash payment 
method, parking lot availability, supply continuity, hygiene of selling point, service acceleration in counter, and employee's hospitality.

3. Quadrant III was the lowest considered, most significantly unimportant and unexpected factors of level of perception and performance by consumers, so that management of supermarkets did not necessarily prioritize or give high concern to those factors. These attributes were halal label, separated outlet, brochure and packaging.

4. Quadrant IV comprised of the most considered and highly unimportant and unexpected by consumers, so that management of supermarkets did not more allocated any resources related to such factors to other factors having higher priority. Such attributes included in this quadrant were fat information, beef's slices, storage's temperature, payment method by credit card, toilet, service counseling by employee and employee's uniform tidiness.

\section{Conclusion}

Eventually, consumer behavior of beef in both supermarkets, located in District of South BolaangMongondow, Province of NorthSulawesi shows that attribute of expired date, beef's parts, and halal label were significantly important, but its performance had not been in line with consumers' demand in making purchasing decision. Since those three attributes of beef were required higher priority by management of supermarkets and beef producers in improving beef's quality in order to meet consumers' demand as they wanted to buy beef products.

While, attributes of beef, consisting of nutrition, beef's color, texture, price, cash payment method, supply continuity, availability of parking lot, hygiene of selling point, service acceleration in counter and employee's hospitality in serving consumers were necessarily considered to be important issue and it had showed preferable performance in accordance with consumers' demand. Therefore, such condition should be maintained continuously by either management of supermarkets or beef producers.

\section{References}

[1] Demirtas, B (2018). The effect on price increases on fresh meat consumption in Turkey. Acta Universitatis Agriculture et Silviculture Mendelianae Brunensis, 66 (5), 1249-1259.

[2] Mateja K. K, and Vida I (2009). A Strategic household purchase: Consumer house buying behavior. Managing Global Transitions. 7 (1), 75-96.

[3] Center for Statistic Bureau of North Sulawesi (2018). South Bolaang Mongondow in Figures. Statistical Office, Manado, North Sulawesi Province.

[4] Tjiptono, F (2008). Strategi Pemasaran Edisi 3, ANDY Yogyakarta.
[5] Tafuli, C. R. V, Hartono B, Nugroho B. A (2012). Analisis tingkat kepentingan dan Kinerja Atribut-atribut daging sapi bali yang beredar di Kota Kupang Provinsi Nusa Tenggara Timur. Sains Peternakan. 11 (1), 19-25.

[6] Kiran M, Nithin P. K, Paramesha S. C, Rajshekar T, Praveen M. P, Punitkumar C, Puneetha S. C, Kumar R, Rahul Y, and Nagabhushan C (2018). Consumption pattern, consumer attitude and consumer perception on meat quality and safety in Southern India. International Food Research Journal, 25 (3), 1026-1030.

[7] Njazi B, Arben V, Mustafe P, Ardita J, and Hysen B (2012). Analysis of consumer behavior in regard to the beef meat in Kosovo. Food and Nutrition Sciences. 3, 1514-1521.

[8] Purwono J, Sugyaningsih S, and Andryani M. (2014). Analisis keputusan pembelian daging sapi oleh konsumen rumah tangga (kasus Hypermarket Taman Yasmin Bogor). Jurnal Neo-Bis, 8 (1), 77-92.

[9] Villalobos P, Padilla C., Ponce C, and Rojas A (2010). Beef consuimer preferences in Chile: Importance of quality attribute differentiators on the purchase decision. Chilean Journal of Agricultural Research. 70 (1), 85-94.

[10] Uys P, and Bisschoff C. A (2016). Identifying consumer buying preferences of beef. Problems and Perspectives in Management. 14 (4), 256-263.

[11] Giacomazzi C. M, Talamini E, and Kindlein L. (2017). Relevance of brands and beef quality differentials for the consumer at the time of purchase. RevistaBrasileira de Zootecnia. 46 (4), 354-365.

[12] Sugiyono (2010). Metode Penelitian Pendidikan Pendekatan Kuantitatif, kualitatif, dan R \& D. Bandung: Alfabeta.

[13] Santoso S (2017). StatistikMultivariantDengan SPSS. PT. Elix Media Kemputindo. Jakarta.

[14] Sevilla C. G, Jesus A. O, Twila G. P, Bella P. R, and Gabriel G. U (1993). MetodePenelitian. Universitas Indonesia (UI) Press.

[15] Sukardi, and Chandrawatisma C. (2006). Analisis Tingkat KepuasanPelangganTerhadapProdukCornet Produksi PT. CIP, Denpasar, Bali. JurnalTeknologiIndustriPertanian. 18 (2), 106117.

[16] EboliL, and Mazzulla G (2009). New customer satisfaction index for evaluating transits Service quality. Journal of Public Transportation. 12 (3), 21-37.

[17] Sekaran U (2014) Research Methods for Busines (4thed.) Erlangga, Jakarta.

[18] Kotler P (1994). Marketing Managemen. A Paramount Comunication Compoany, Englewood Clifs, New Jersey.

[19] Kotler P, and Amstrong G (2012). Prinsip Prinsip Pemasaran. Edisi 13, Jilid 1. Erlangga, Jakarta; 2012.

[20] Xazela N. M., Hugo A, Marume U, and Muchenje V (2017). Perceptions of rural consumers on the aspects of meat quality and health implications associated with meat consumption. Sustainability. 9 (5), 830.

[21] Merlino V. M, Borra D, Verduna T, and Massaglia S (2017). Household behavior with respect to Meat Consumption: Differences between Households with and without Children. Veterinary Sciences. 2017; 4 (4): 53. 
[22] Giacomazzi C. M, Talamini E, and Kindlein L (2017). Relevance of brands and beef quality differentials for the consumer at the time of purchase. Revista Brasileira de Zootecnia, 46 (4), 354-365.

[23] Arum R, and Bhuvaneswari R (2019). Buying behavior of meet's consumption relates to food safety from north and south part of the Coimbatore City. International Journal of Recent Technology and Egineering, 7, 429-433.

[24] Laorden N. L, and Bangcaya A. P (2013). Consumers' purchasing behavior towards fresh meat in Davao City, Philippines. Banwa, 10 (1), 50-64.

[25] Bisschoff C. A, and Liebenberg C. L. (2017). An analysis of consumer preferences of meat in a typical South African township. Journal of Contemporary Management. 14 (1), 554594.
[26] Merlino V. M., Borra D, Verduna T, and Massaglia S (2017). Household behavior with Respect to Meat consumption: differences between households with and without children. Veterinary Sciences. 4 (4): 53.

[27] Radman M., Camanzi L, and Kolega A (2005). Preferences and buying behavior of beef consumners in Tuscany. Journal of Central European Agriculture. 6 (1), : 99-106.

[28] Petroman C., Ionela C. B, PetromanI, Sucan M, Marin D, Turc B, Merce J, andConstantin E. C. (2015). The impact of education on the behaviour of the consumer of animal origin food products. Procedia - Social and Behavioral Sciences. $190,429-433$ 